\title{
Sedimentological and palynological constraints on the basal Triassic sequence in Central Switzerland
}

\author{
Christian Gisler ${ }^{1,2}$, Peter A. Hochuli ${ }^{3}$, Karl Ramseyer $^{1, *}$, Hansruedi Bläsi $^{1}$ \& Fritz SchlunegGer $^{1}$
}

Key words: Alpine Triassic, Switzerland, palynomorphs, stratigraphy, palaeogeography

\section{ABSTRACT}

In Central Switzerland, Mesozoic sedimentation began after erosion and peneplainisation of the Hercynian relief and late Paleozoic continental deposition in SW-NE striking pull-apart basins. The first Triassic sedimentary sequence overlaying a weathered crystalline basement consists of a relatively thin $(<10$ $\mathrm{m})$, lithologically highly variable unit with coarse-grained siliciclastic deposits at the base, grading into a mixed sandstone/shale-dolomite sequence followed by well-bedded dolomites with chert nodules.

Sedimentary texture analyses and petrological investigations revealed four different sedimentary units starting at the base with a regolith unit that represents the weathered crystalline basement. It is overlain by terrestrial plain deposits, followed by mixed siliciclastic-carbonaceous sediments and a sequence of dolomites, deposited between the supralittoral and eulittoral zones of a tidal flat (Mels-Formation), and the eulittoral to sublittoral zones of a carbonate tidal flat environment (Röti-Dolomit), respectively.

Palynological data from four localities in Central Switzerland indicate a heterochronous early Anisian age (Aegean - Bithynian/Pelsonian) for the supra- to eulittoral mixed siliciclastic-carbonaceous sediments. These new biostratigraphic ages suggest that the first Triassic marine transgression in Central Switzerland is time equivalent with those of the basal Wellendolomit in Northern Switzerland but slightly older than in the Germanic Basin. Consequently, Central Switzerland was located at this time at the northern shoreline of the Tethys and not on the southern limit of the Germanic Basin.

\section{ZUSAMMENFASSUNG}

Die mesozoische Sedimentation begann in der Zentralschweiz nach einer erosiven Phase des herzynischen Gebirges und der Ablagerung spätpaläozoischer klastisch-kontinentaler Sedimente in SW-NE gerichteten transpressiven Gräben. Die frühesten triadischen Ablagerungen, die den verwitterten kristallinen Untergrund überdecken, sind eine meist geringmächtige $(<10 \mathrm{~m})$ Sequenz von grobkörnigen Siliziklastika, gefolgt von einer Wechsellagerung von Sandsteinen, Tonsteinen und Dolomit, die durch gut gebankte Dolomite mit Hornstein-Konkretionen überlagert werden.

Detaillierte sedimentologische und petrographische Analysen führten zur Unterteilung der Sequenz in 4 Einheiten, beginnend mit einem basalen Regolith, dem Verwitterungsgrus des kristallinen Untergrundes. Im Hangenden folgt als erstes eine terrestrische, siliziklastische Einheit, die von einer suprabis eulitoralen siliziklastisch-karbonatischen Wechselfolge einer Wattenfläche (Mels-Formation) überlagert wird. Im Hangenden treten gut geschichtete Dolomite des eu- bis sublitoralen Bereichs eines Karbonatwatts (Röti-Dolomit) auf.

Palynologische Daten von vier Lokalitäten in der Zentralschweiz deuten auf eine heterochrone marine Transgression (Aegean bis Bithynian/Pelsonian) der supra- bis eulitoralen, siliziklastisch-karbonatischen basalen Triassedimente hin. Diese neuen biostratigraphischen Daten zeigen, dass die erste marine Transgression in der Zentralschweiz zeitgleich mit derjenigen in der Nordschweiz (Basaler Wellendolomit) ist, aber etwas älter als jene im nördlich anschliessenden Germanischen Becken. Die Zentralschweiz befand sich somit zur Zeit der frühen Trias an der Nordküste der Tethys und nicht am Südrand des Germanischen Beckens.

\section{Introduction}

The onset of Mesozoic sedimentation above the crystalline basement has fascinated geologists since the end of the $18^{\text {th }}$ century (e.g., De Saussure 1796; Escher von der Linth 1797; Lusser 1829, 1842). Both, the striking lithological change as well as the angular unconformity between the yellowish, well- bedded dolomites and the grayish, massive crystalline rocks attracted attention of these early naturalists. Since then, numerous geologists, such as Studer (1853), Baltzer (1880), Königsberger (1909), Arbenz (1913), Heim \& Heim (1917) or Rohr (1926) refined the knowledge on the stratigraphic allocation, depositional environment and palaeogeographic setting of the

\footnotetext{
${ }^{1}$ Institut für Geologie, Universität Bern, Baltzerstrasse 1+3, CH-3012 Bern

${ }^{2}$ B-I-G, Büro für Ingenieurgeologie AG, Dorfstrasse 10, 3073 Gümligen-Wabern

${ }^{3}$ Paläontologisches Institut, Universität Zürich, Karl Schmid-Strasse 4, CH-8006 Zürich

Correspondense to: Karl Ramseyer. E-mail: karl.ramseyer@geo.unibe.ch
} 


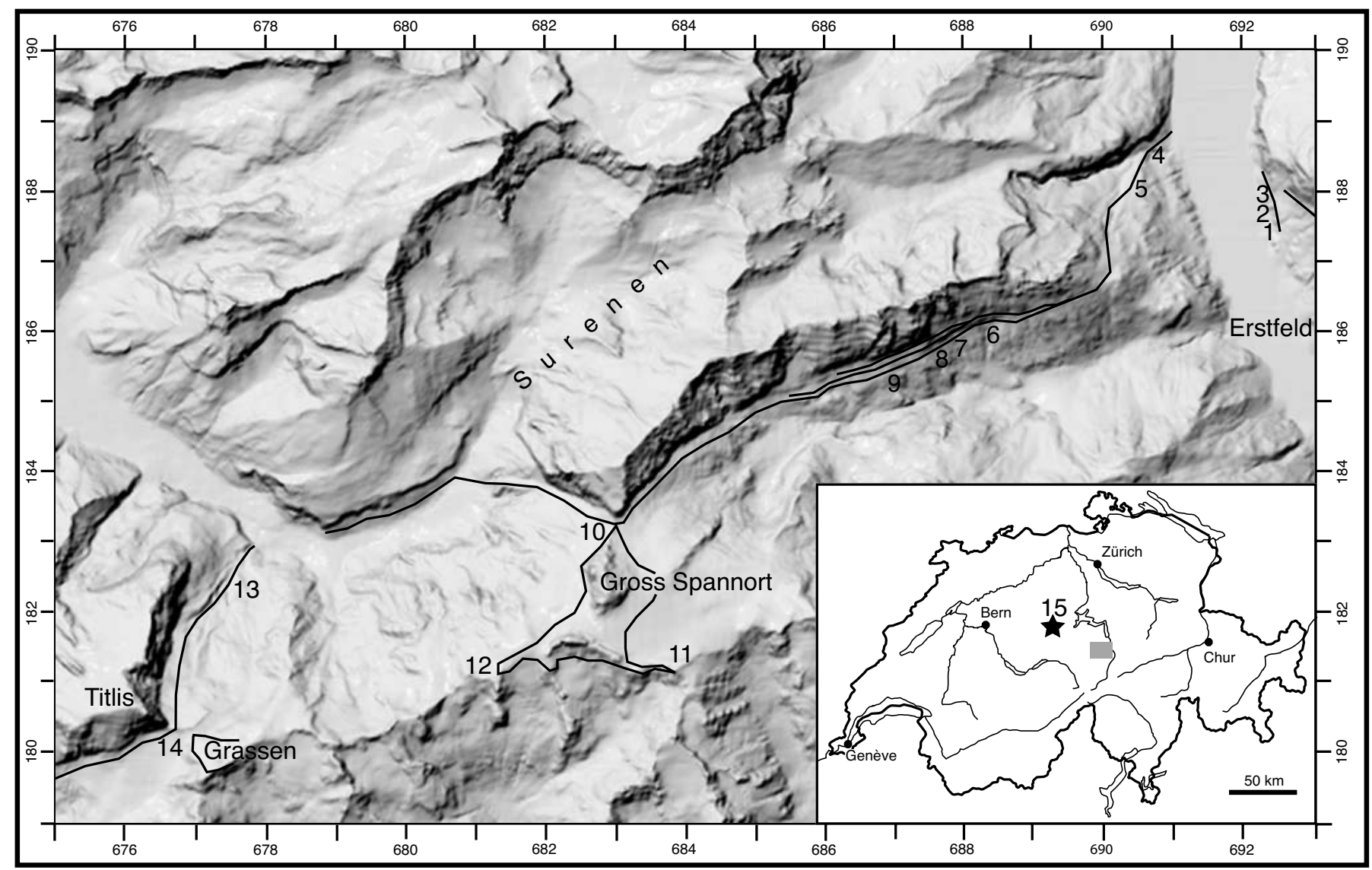

Fig. 1. Digital elevation model (Hurni et al. 2000) of the study area in Central Switzerland with outline of the basal Triassic sequence and positions of the examined 14 sections. 1: Girenbiel, 2: Scheidnössli south, 3: Scheidnössli, 4: Bockitobel, 5: Bockiberg, 6-9: Sunnig Täler I-IV, 10: Schlossberglücke, 11: Glattpass, 12:

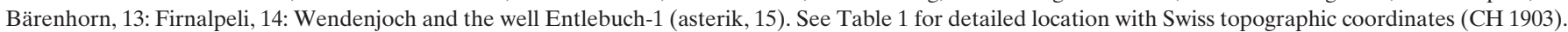
Reproduced with permission of Swisstopo (BA068103).

sedimentary sequence covering the crystalline basement in Central Switzerland. In their views, the Triassic section is composed of a basal clastic unit, the Mels-Formation, an intermediate dolomitic unit, the Röti-Dolomit and, if present on the top, a red silty sandstone unit with a basal dolomitic breccia, the Quarten-Formation. Yet, conflicting views exist about the assignment of these units to depositional environments. Particularly, it has been unclear whether these formations were deposited in a shallow marine and/or terrestrial setting. Similarly, allocation to lithostratigraphic units, i.e., to Buntsandstein or Muschelkalk has been controversial, and as a consequence the correlation with the well established Triassic section of the Jura Mountains in Northern Switzerland (Matter et al. 1988) has remained ambiguous. These uncertainties were well summarized by Trümpy (1959), who proposed two possibilities: either the Mels-Formation is the marine equivalent of the terrestrial Upper Buntsandstein of Northern Switzerland or represents the basal transgression of the Muschelkalk Sea onto the Vindelician High. The first hypothesis implies that either the Burgundy gate or after Einsele \& Schönenberg (1964) and Szulc (2000) at a more easterly located gateway (e.g., Western
Gate) opened earlier than generally believed, or that the position of the Vindelician High is further north, e.g., at the southern limit of the Molasse Basin. Furthermore, in Central Switzerland the Triassic sedimentary record suggests that it was rather controlled by the marine conditions of the Tethys than by those of the epicontinental Germanic Basin. This statement, however, requires that the transgression progressed from the Tethyan realm and not from the Germanic Basin. The second possibility of Trümpy's suggestions implies that the terrestrial Upper Buntsandstein is missing, and that the sedimentary processes in the Central Alps were most likely linked to the conditions in the Germanic Basin. Trümpy (1959) favoured the $2^{\text {nd }}$ hypothesis, but indicated that biostratigraphic data are necessary to proof it.

Recent advances in sedimentology, interpretation of depositional environments, new palynostratigraphic data and sequence stratigraphic correlations for the Triassic period of the Germanic Basin and the Tethys Ocean (Aigner \& Bachmann 1992; Hagdorn \& Seilacher 1993; Götz 1996; Gianolla \& Thierry 1998; Hochuli 1998; Bachmann \& Lerche 1999; Szulc 2000; Feist-Burkhardt et al. submitted) allow a new look at these 
open questions. The aims of this paper are to (i) reconstruct the depositional environments of the basal Triassic of Central Switzerland and to (ii) provide palynostratigraphic data. Based on this information we discuss the palaeogeographic implications and will address the question whether the transgression on the Vindelician High progressed from the Germanic Basin or from the Tethys.

\section{Geologic setting and sampling sites}

The investigated area is located at the northern border of the Aar Massif (Fig. 1) between the Reusstal in the east and the Titlis in the west. In the studied locations, a sequence of Triassic to Tertiary sediments, unconformably overlays weathered Erstfeld Gneiss, the Innertkirchen Crystalline and a zone of interlayered thrust sheets of Carboniferous metapelites and metaconglomerates. A good overview of the regional geology is found in Rohr (1926) and Heim \& Heim (1917) who meticulously studied the Triassic to Middle Jurassic sequence of this area and the Scheidnössli location in particular.

A total of 14 sections located on both sides of the Reusstal (Fig. 1; Table 1) were analyzed in detail for sedimentary textures and sampled for microfacies analyses and palynomorphs. Further material and data were obtained from the exploration well Entlebuch 1 (Fig. 1; Vollmayr \& Wendt 1987; SEAG, Aktiengesellschaft für Schweizerisches Erdöl, Winterthur).

\section{Results}

\section{Sedimentary environments}

The detailed sedimentological logging of the sections from both sides of the Reusstal reveals that the basal Triassic above the crystalline basement and its regolith cover comprises three units. These are from base to top (i) a sequence of dm- to m-thick sandstone beds, (ii) an alternation of sandstones, claystones and dolomites with chert nodules, and (iii) a succession of dolomite beds with chert nodules (Figs. $2+3$ ).

\section{Crystalline basement and regolith cover}

The crystalline basement consists of a migmatitic biotiteplagioclase gneiss that experienced a Caledonian metamorphosis. The primary metamorphic fabric is readily visible in most sections $>100 \mathrm{~cm}$ beneath the base of the sandstone unit. Towards the top, the basement displays a relatively indistinctive red to yellow mottling and occasionally comprises carbonate concretions. Thicknesses are highly variable, ranging from the $\mathrm{dm}$ - to the m-scale. In this zone mineral transformations include the disappearance of both plagioclase and apatite, and their volumetric replacement by microcrystalline quartz, sericite and calcite. K-feldspar is less altered, but comprises neomorphic microcrystalline quartz and sericite and an opaque Feoxide phase. Decolorized biotite contains numerous $\mu \mathrm{m}$-sized opaque Ti-oxide phases. In some locations, the sandstone unit
Table 1. Studied sections in Central Switzerland. For locations see Figure 1

\begin{tabular}{|lrll|}
\hline Region & Number & Locality & Coordinates \\
\hline Reusstal & 1 & Girenbiel & $692425 / 187550$ \\
Reusstal & 2 & Scheidnössli south & $692350 / 187600$ \\
Reusstal & 3 & Scheidnössli & $692350 / 187700$ \\
Reusstal & 4 & Bockitobel & $690750 / 188500$ \\
Reusstal & 5 & Bockiberg & $690550 / 188150$ \\
Erstfeldertal, northern flank & 6 & Sunnig Täler I & $688250 / 186050$ \\
Erstfeldertal, northern flank & 7 & Sunnig Täler II & $687850 / 185950$ \\
Erstfeldertal, northern flank & 8 & Sunnig Täler III & $687820 / 185920$ \\
Erstfeldertal, northern flank & 9 & Sunnig Täler IV & $686900 / 185430$ \\
Gr. Spannort, northern side & 10 & Schlossberglücke & $683000 / 183150$ \\
Chli Spannort & 11 & Glattpass & $683100 / 181375$ \\
Chli Spannort & 12 & Bärenhorn & $681325 / 181000$ \\
Titlis, eastern side & 13 & Firnalpeli & $677480 / 182350$ \\
Titlis, eastern side & 14 & Wendenjoch & $676650 / 180450$ \\
\hline
\end{tabular}

described below follows upon the crystalline basement with the primary metamorphic fabric, and the zone of mottling is missing.

We interpret the top of the crystalline basement to represent either a regolith cover formed by weathering or an erosional surface. Regolith cover is interpreted at locations where the top of the crystalline basement displays mottled fabric, the above stated mineral transformations, and carbonate concretions (Fig. 3). These features are related to chemical weathering of the crystalline bedrock at varying levels of the ground water table (Wright \& Tucker 1991). The carbonate concretions are interpreted as dolocrete nodules that formed by groundwater evaporation in the vadose zone of the regolith under semi-arid to arid conditions (Wright \& Tucker 1991). Regional variations in regolith thickness are considered either as a result of different weathering rates or of surface erosion prior to deposition of the sandstone unit. The top of the crystalline basement is interpreted as erosional surface in locations where the sandstone unit directly overlies the unweathered basement.

\section{Sandstone unit}

The sandstone unit starts with a max. $3 \mathrm{~m}$-thick sequence of medium- to coarse-grained sandstones and ends with a less than $1 \mathrm{~m}$-thick amalgamation of fine- to medium-grained sandstone beds (Figs. $2+3$ ). The petrographic composition of the succession is dominated by quartz fragments with admixtures of dolomite and chert particles that increase in abundance upsection. The coarse-grained sandstone beds at the base are generally massively bedded and poorly sorted. At Scheidnössli cross-stratified sandstone interbeds with a flat base are present (Fig. 2). The overlying fine-grained sandstone beds are wellsorted, and show mm-thin parallel lamination. Towards the top, $\mathrm{cm}$ - to dm-thick beds with ripple marks, flaser-, wavy- and lenticular bedding and with mm-thick coarse-grained sandstone interbeds become increasingly abundant.

The massive texture, observed in the coarse-grained sandstone beds, suggests episodic transport of sediment presum- 


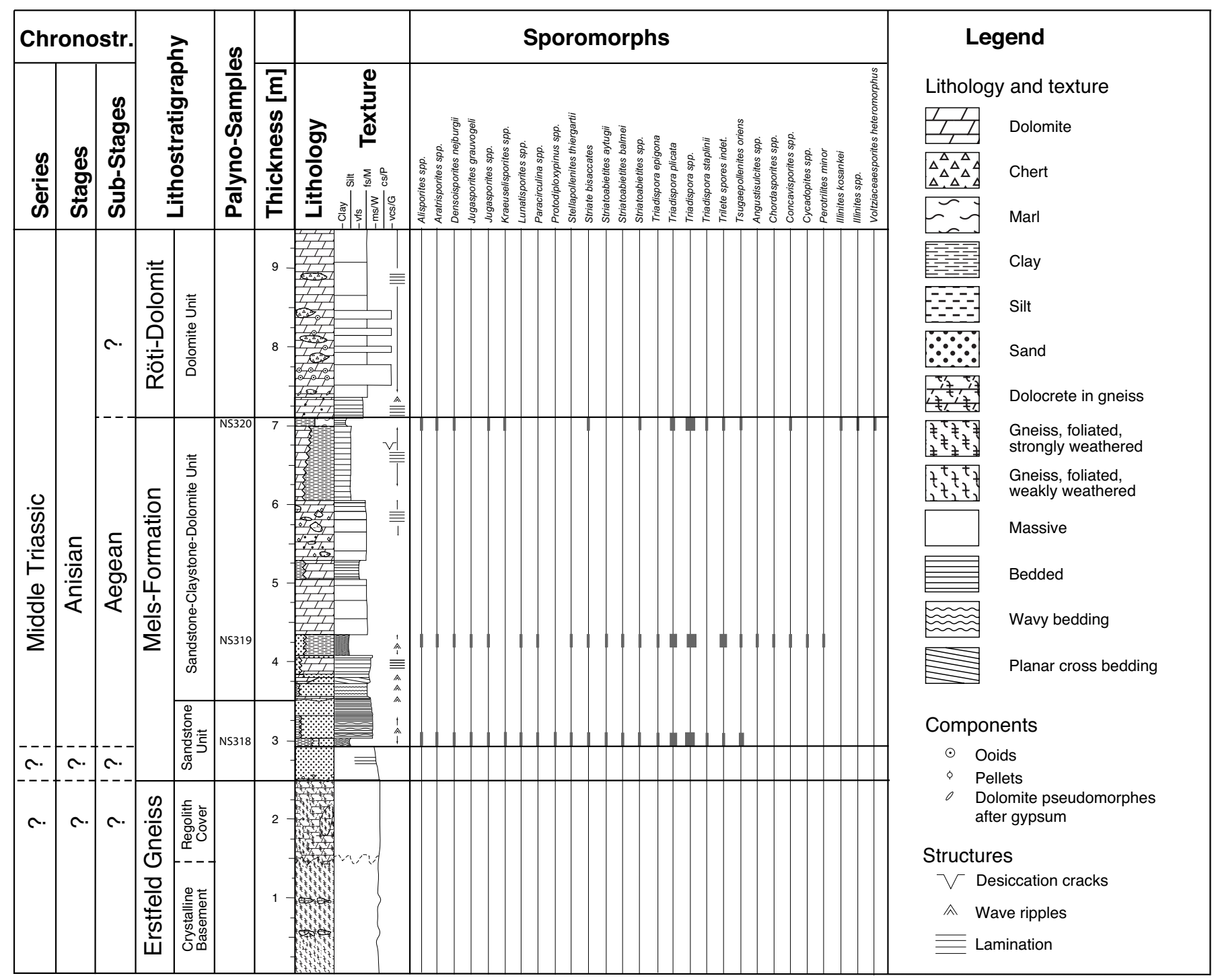

Fig. 2. Stratigraphy of the Scheidnössli section with chronostratigraphic interpretation, lithology and distribution of palynomorphs.

ably as granular flows (Platt \& Keller 1992). The presence of cross-stratified beds with a flat base indicates occasional transport of sand grains as bedload by unconfined subcritical flows (Southhard 1991). The combination of these sedimentological features indicates deposition on a gently dipping terrestrial plain presumably under arid climatic conditions (e.g., Jordan et al. 2001).

In contrast, the mm-thin parallel lamination and the wellsorted nature of the medium- to fine-grained sandstone beds suggest deposition at continuously critical to supercritical flow conditions (Southhard 1991). Such a situation is usually encountered in upper shoreface environments (e.g., Keller 1989). The flaser-, wavy- and lenticular bedding found in the overlying beds implies periodically changing flow conditions in the lower flow regime. Such conditions are commonly found on tidal flats (e.g., Flemming 2004). The mm-thick coarse-grained sandstone interbeds then represent high-energy floods deposited during storm events. In summary, the upper portion of the sandstone unit is assigned to a tidal environment with shoreface sandstones of the lower eulittoral, and tidal flat deposits of the upper eulittoral (e.g., Keller 1989).

Sandstone-claystone-dolomite unit

The unit with a sandstone-claystone-dolomite alternation is about $3 \mathrm{~m}$-thick (Figs. $2+3$ ). It starts with an alternation of fine-grained sandstones and claystones and ends with alternating dolomites and claystones. Individual beds are several $\mathrm{cm}$ to $\mathrm{dm}$ thick. The sandstone-mudstone alternation displays wavy-, lense- and flaser-bedding. Towards the top of the unit, some of the dolomite beds show a polygonal surface texture with vertically-oriented cracks. Wavy parallel-lamination together with 


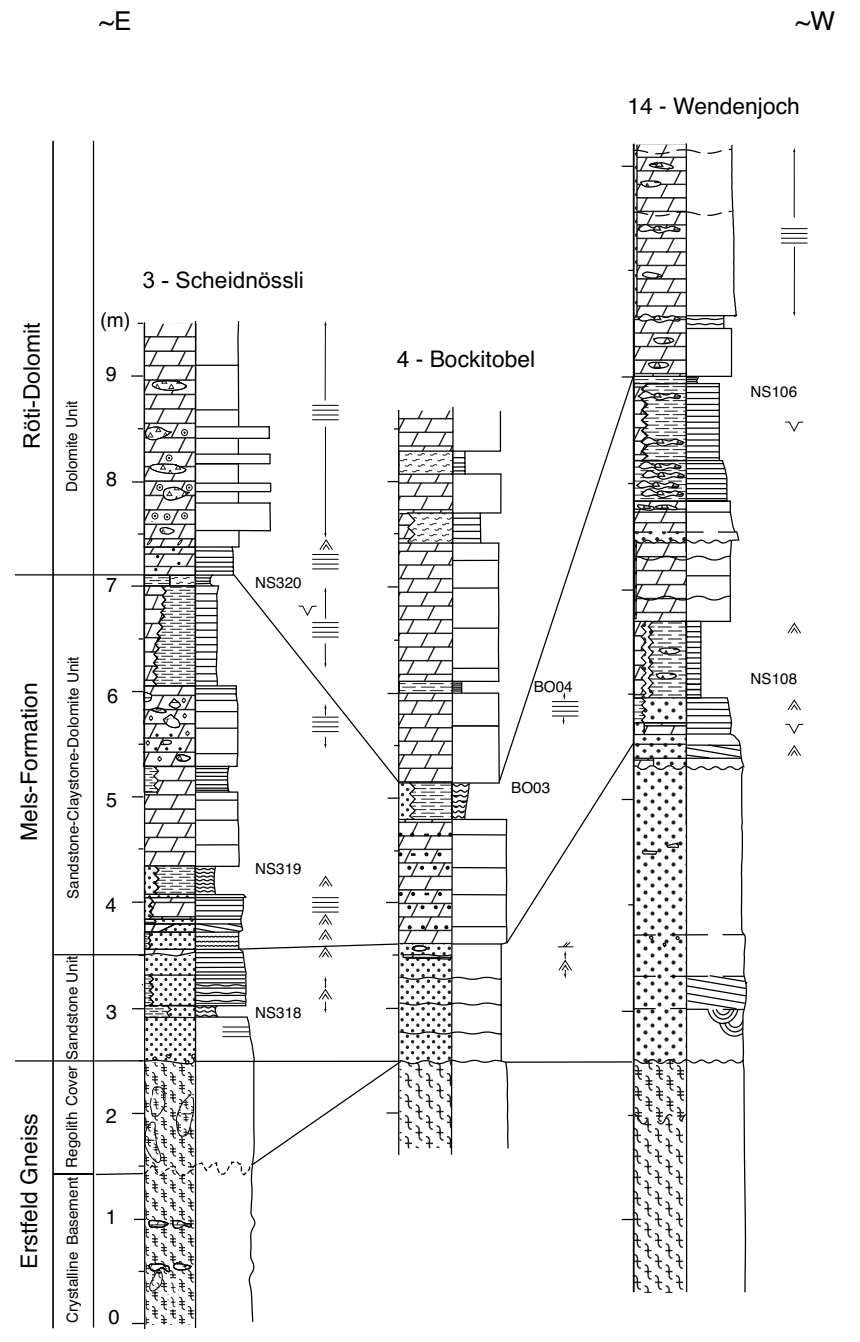

mm-thin coarse-grained sandstone interbeds and chert nodules are frequently observed. The interbedded claystones are either massive or parallel-laminated. Microscopic analyses of the dolomites reveal that some beds represent mudstones with admixture of very fine-grained quartz grains, or contain abundant pellets and bioclasts. Fenestral fabric is frequently observed.

Based on the presence of wavy-, lense- and flaser-textures we assign the sandstone-claystone-dolomite alternation to the upper eulittoral/supralittoral of a tidal flat environment. Further up-section, the wavy lamination of the dolomites and the polygonal surface texture with vertically-oriented cracks suggest that carbonaceous mud was trapped by microbial mats that occasionally dried out (Alsharhan \& Kendall 2003). These features, together with fenestral fabric, support the interpretation of a tidal flat. The chert nodules represent either silcrete horizons or are pseudomorphoses of evaporite nodules. If this interpretation is correct, the upper eulittoral deposits became part of the supralittoral during a later regression stage (Kenig et al. 1991).
Lithology and texture

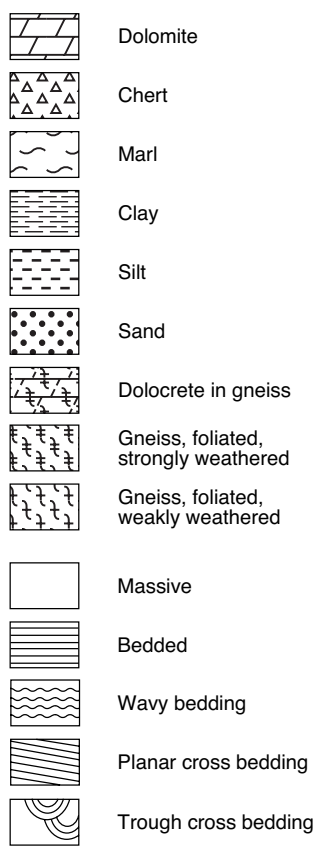

Components

$\odot$ Ooids

$\checkmark$ Pellets

- Dolomite pseudomorphes after gypsum

\section{Structures}

$\checkmark$ Desiccation cracks

// Current ripples

A Wave ripples

$\equiv$ Lamination

Dolomite unit

The uppermost unit corresponding to the Röti-Dolomit comprises a 10-25 $\mathrm{m}$ thick sequence of dolomites (Figs. $2+3$ ). It starts with a $20 \mathrm{~cm}$-thick bed consisting of coarse-grained dolomite crystals. Pseudomorphic replacement of gypsum crystals by dolomite is frequently observed. The overlying dolomite beds are alternating oolithic grainstones and mudstones, occasionally comprising chert nodules.

As indicated by the pseudomorphic replacement of gypsum crystals the base of the dolomite unit is interpreted as deposit of a tidal flat in the supralittoral zone. However, the succeeding alternation of mudstones and grainstones implies deposition in the lower eulittoral to sublittoral zone after a transgression.

\section{Palynology and Palynofacies}

Shale-rich, fine-grained, siliciclastic sediments from the sandstone unit and from the top of the sandstone-claystonedolomite unit were selected for palynological analyses. In all 

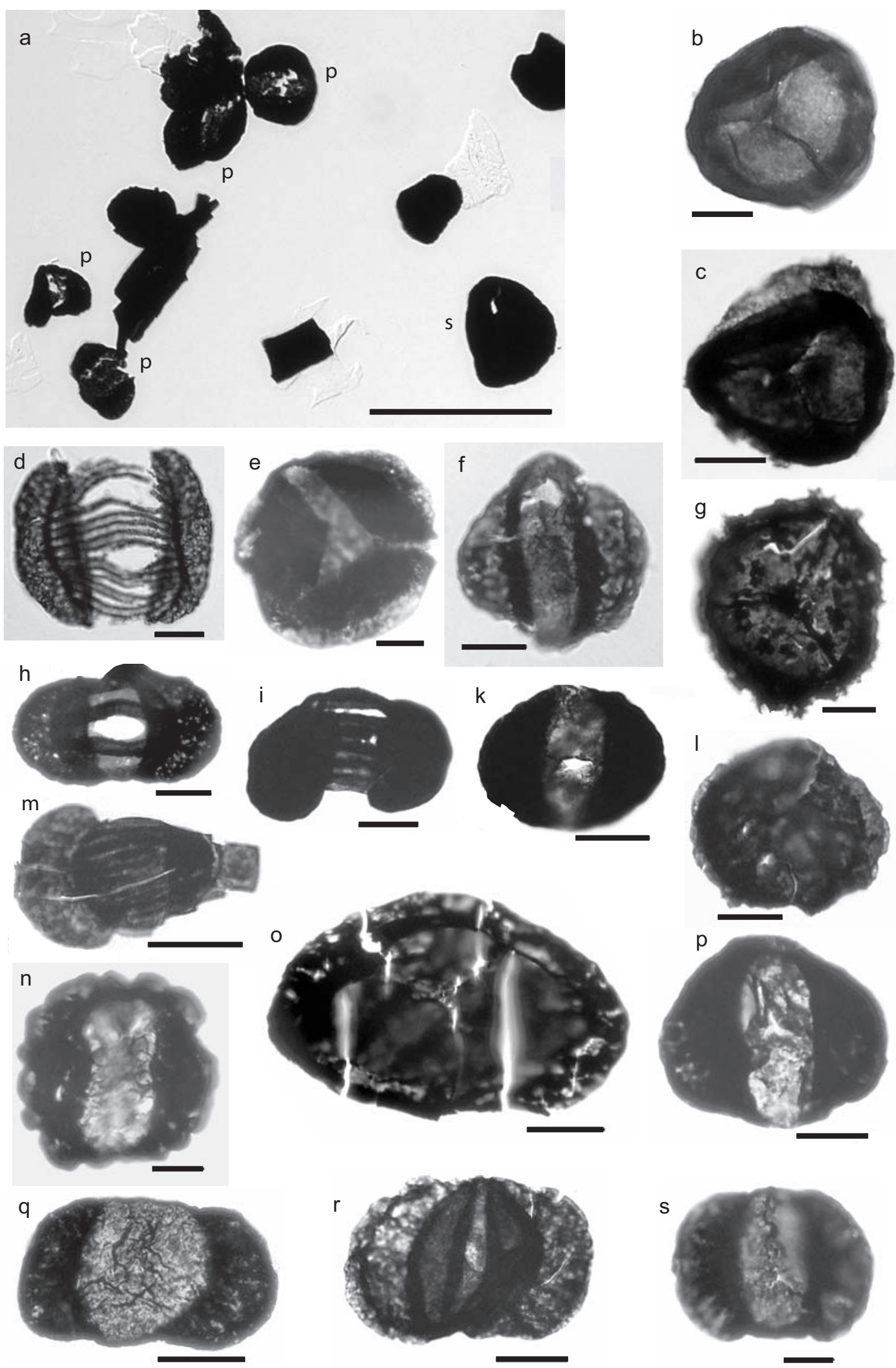
samples the organic matter consists of thermally altered mostly opaque phytoclasts and palynomorphs of terrestrial origin. Some of the phytoclasts are relatively large, suggesting that the depositional environment was relatively close to the source. Palynomorphs of marine origin were not observed; however, considering the poor state of preservation of the organic matter, their absence does not necessarily contradict the sedimentological evidence indicating marine conditions.

The observed colors of palynomorphs correspond to level $6 / 7$ on the thermal alteration scale (TSA) of Batten (1996). In the vitrinite reflectance scale this level corresponds to values of about $2-3 \% R_{o}$ and in terms of metamorphic grades to the anchizone. Fluid inclusion studies in fissure quartz from this region (Mullis et al. 1994) indicate that the peak alpine metamorphic temperature was between 270 and $300{ }^{\circ} \mathrm{C}$ or at the boundary between anchi- and epizone. The slightly cooler conditions referred from the TSA of palynomorphs than from the fluid inclusions in quartz may be real and probably due to special chemical conditions of the depositional environment, e.g., anoxic conditions (Batten 1996).

\section{Scheidnössli}

The richest samples with the best preserved palynomorphs come from the Scheidnössli section (Fig. 1). Three samples (NS318, NS319 and NS320) are relatively rich in organic matter of terrestrial origin including numerous spores and pollen grains (Figs. $2+4$ ). The richest and best preserved assemblage has been found in sample NS318 from the sandstone unit. In this sample most pollen grains are still partly translucent and well preserved structures are discernable. The assemblages of all three samples are strongly dominated by bisaccate pollen grains, especially by representatives of the Triadispora group; Triadispora plicata being one of the most common species (cf. Figs. $2+4)$. Other bisaccate pollen grains like Alisporites, Jugasporites and taeniate bisaccates, including Striatoabieites,
Protodiploxipinus and Lunatisporites are regularly represented. Rare species include Stellapollenites thiergartii, Illinites spp., I. kosankei and Angustisulcites spp. (cf. Figs. 2+4).

Beside indeterminate, mostly opaque trilete spores, a few taxa could be determined (Fig. 4) such as Aratrisporites spp., Densoisporites nejburgii, Kraeuselisporites spp. and the very long ranging genus Concavisporites.

\section{Wendenjoch}

Two samples (NS106 and NS108) were prepared from the Wendenjoch section (Fig. 3). Sample NS108 contains strongly carbonized indeterminable organic debris, whereas palynomorphs are relatively common in sample NS106. Bisaccate pollen grains, especially representatives of the Triadispora group are common. Specimens similar to the marker species Stellapollenites thiergartii have been recorded. However, the poor state of preservation does not allow definite determination of this species. Ovalipollis, a diagnostic group for the upper part of the Middle and for the Late Triassic was not found, although its presence could easily be detected due to its diagnostic shape. Thus, pollen of the Ovalipollis group may be rare or absent from this sample. Taeniate bisaccate pollen grains are relatively rare; species such as Lunatisporites spp., Protohaploxipinus spp., Striatoabieites spp. or St. aytugii occur sporadically. Spores are also rare, only Aratrisporites spp. and Porcellispora longdonensis could be determined.

\section{Bockitobel}

The organic material in the samples BO03 and BO04 from the Bockitobel section (Fig. 3) consists essentially of thermally altered opaque phytoclasts. Palynomorphs are very rare; only few specimens of the Triadispora group have been found. Spores are also present; however their specific determination is hampered because of the opaque nature of the dense walls. Similarly, particles of woody origin are also only discernable by their shape.

\footnotetext{
Fig 4. Typical sporomorphs from the Scheidnössli section.

a Palynofacies, showing phytoclasts, bisaccate pollen grains (p) and spores (s). Sample NS318, scale bar: $100 \mu \mathrm{m}$

b Densoisporites nejburgii (Schulz) Balme 1970, sample NS318, scale bar: $10 \mu \mathrm{m}$

c Densoisporites cf. nejburgii (Schulz) Balme 1970, sample NS318, scale bar: $20 \mu \mathrm{m}$

d Striatoabieites cf. balmei Klaus 1964, sample NS318, scale bar: $10 \mu \mathrm{m}$

e Stellapollenites thiergartii (Mädler) Clement-Westerhof 1974, sample NS318, scale bar: $10 \mu \mathrm{m}$

f Sulcosaccispora? sp., sample NS320, scale bar: $10 \mu \mathrm{m}$

g Kraeuselisporites sp., sample NS318, scale bar: $10 \mu \mathrm{m}$

h Protohaploxipinus sp., sample NS318, scale bar: $20 \mu \mathrm{m}$

i Lunatisporites sp., sample NS318, scale bar: $20 \mu \mathrm{m}$

k Jugasporites sp., sample NS318, scale bar: $20 \mu \mathrm{m}$

1 Perotriletes minor (Mädler) Antonescu \& Taugourdeau Lantz 1973, sample NS319, scale bar: $10 \mu \mathrm{m}$

m Striatoabieites sp., sample NS320, scale bar: $20 \mu \mathrm{m}$

n Tsugaesporites oriens Klaus 1964, sample NS318, scale bar: $10 \mu \mathrm{m}$

o Illinites sp., sample NS320, scale bar: $20 \mu \mathrm{m}$

p Triadispora cf. epigona Klaus 1964, sample NS318, scale bar: $20 \mu \mathrm{m}$

q Triadispora plicata Klaus 1964, sample NS318, scale bar: $20 \mu \mathrm{m}$

r Voltziaceaesporites heteromorphus Klaus 1964, sample NS318, scale bar: $20 \mu \mathrm{m}$

s Triadispora sp., sample NS318, scale bar: $10 \mu \mathrm{m}$
} 


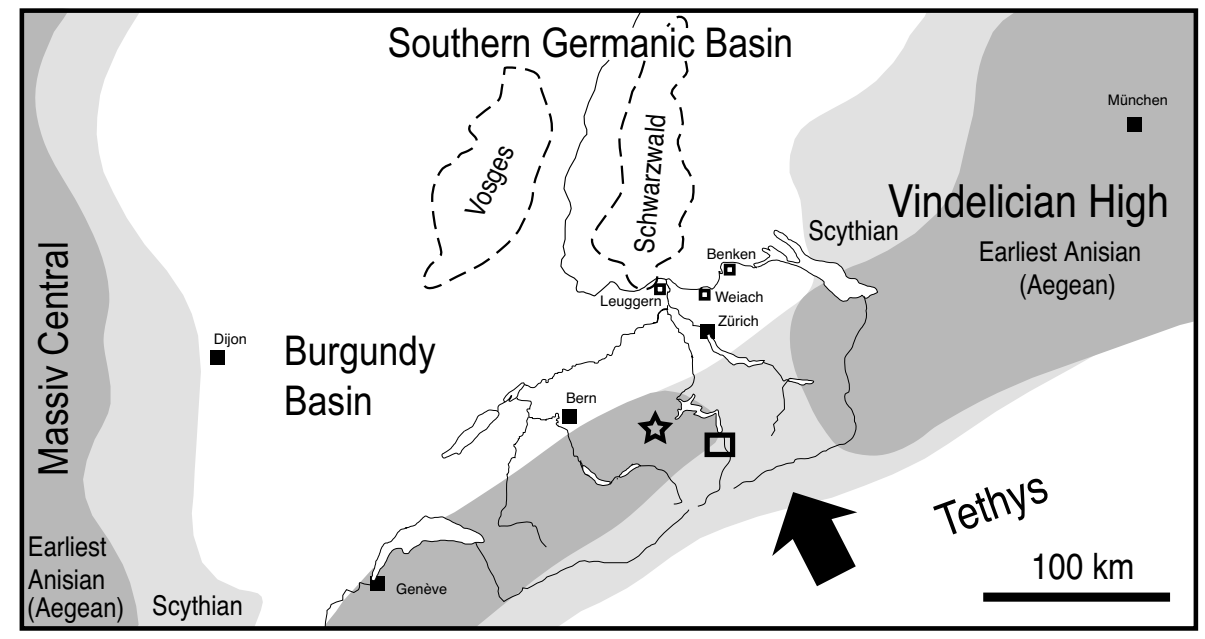

Fig. 5. Palaeogeographic situation showing the location of the Vindelician High during Early Triassic and earliest Anisian (Aegean) times, after Ricour (1963), Ziegler (1990), and this study with the position of the Entlebuch-1 well (asterik), the wells Leuggern, Weiach and Benken (black box, the study area (rectangle). The arrow indicates the proposed transgression direction and possible marine pathway to Northern Switzerland (Einsele \& Schönenberg 1964). Note that during Aegean times the study area is located at the NW shoreline of the Tethys, and not at the southern limit of the Germanic Basin.

\section{Well Entlebuch 1}

The particulate organic matter in the sample from $5076.9 \mathrm{~m}$ of the Entlebuch-1 well (Fig. 1) is dominated by poorly preserved phytoclasts and palynomorphs. Bisaccate pollen grains are most common. The regular occurrence of the taxa Triadispora spp., Angustisulcites spp., Voltziaceaesporites heteromorphus and Illinites spp. as well as the taeniate bisaccate species Strotersporites spp., Striatoabieites spp., and Lunatisporites spp. are of biostratigraphic relevance. Spores are rare, and only the taxa Calamospora spp., Verrucosisporites morulae, Aratrisporites spp. and Perotriletes minor (syn. Aequitriradites minor) were recorded.

\section{Discussion}

\section{Depositional sequence}

The lower portion of the Mels-Formation records surface erosion and weathering of the Hercynian crystalline and the succeeding establishment of a terrestrial plain. The tidal flat deposits of the upper part of the Mels-Formation and the lower portion of the Röti-Dolomit represent the first marine transgression onto the crystalline basement after the Hercynian orogeny in Central Switzerland. The succession developing from the regolith cover to terrestrial plain and tidal environment requires a continuously increasing accommodation space, which in the present case is interpreted to have gained by a continuous relative sea level rise. Consequently, although the first evidence of marine deposits is found in the upper part the Mels-Formation, the establishment of a terrestrial plain and presumably also the preservation of the regolith cover are consequences of this rising sea level. Hence, the terrestrial deposits at the base of the Mels-Formation represent the first record of the transgressive phase in Central Switzerland.

\section{Biostratigraphy}

For the first time biostratigraphically relevant spore-pollen assemblages could be determined from the basal Triassic sequence of Central Switzerland.

Three samples from the classical Scheidnössli section contain relatively rich palynomorph assemblages of homogeneous composition. The co-occurrence of Stellapollenites thiergartii and Densoisporites nejburgii represents the most important feature of these assemblages. The ranges of the two species overlap only in the lower part of the Anisian (Aegean). The first appearance datum (FAD) of Stellapollenites thiergartii is known from the base of the Anisian, i.e. early Aegean, whereas the last appearance datum (LAD) of Densoisporites nejburgii marks the top of the early Anisian, i.e., late Aegean (Hochuli 1998). Confirming evidence of an Anisian age is the frequent occurrence of Triadispora plicata and the presence of Angustisulcites spp. The two taxa are known to appear near the base of the Anisian. There is no indication of a significant age difference between the samples.

The impoverished assemblages from the Bockitobel section preclude a precise age determination. However, the findings of Triadispora spp. suggest an age similar to the Scheidnössli section.

In the Wendenjoch section the dominant occurrence of the Triadispora group also suggests an Anisian age (Aegean-Pelsonian). Biostratigraphically relevant is the presence of Porcellispora longdonensis. So far the FAD of this species is known in the Alpine Triassic realm from Bithynian and younger sections (Hochuli 1998). Consequently a Bithynian to Pelsonian age range is suggested for sample (NS106), located $6.2 \mathrm{~m}$ above the base of the Triassic section (Fig. 3).

In the sample from the Entlebuch 1 well $(5076.9 \mathrm{~m})$ the presence of the species Perotriletes minor and Strotersporites spp. in association with common bisaccate pollen grains is compatible with an Anisian age.

In all studied localities the shallow-marine fine-grained siliciclastic sediments contain palynomorphs of terrestrial origin 
indicating an Anisian age. So far no palynomorphs have been found in the terrestrial sandy deposits directly overlaying the weathered crystalline basement. The sporomorph assemblages from the Scheidnössli section suggest that the entire shallowmarine siliciclastic unit was deposited during the early Anisian (Aegean). Support for this early marine transgression in Central Switzerland is provided by biostratigraphic data from exploration wells in the French Jura (Dept. Ain), were the first marine sediments transgressing over the Buntsandstein contain palynological assemblages similar to those of the Scheidnössli section (Hochuli pers. information).

A slightly younger Anisian age, i.e., Bithynian to Pelsonian, can be interpreted for the top of the siliciclastic interval (sample NS106) in the Wendenjoch section. Based on this evidence sedimentation of the shallow-marine siliciclastic Triassic sequence appears to be heterochronous (Fig. 5), starting during the Aegean and continuing in the younger part of the Anisian (Bithynian to Pelsonian). Another possibility is that these differences are due to a relief onto which the transgression occurred.

\section{Biostratigraphic correlation of the analyzed sections with Northern Switzerland, the Germanic Basin and the Tethyan realm}

According to the current concept of Middle Triassic palaeogeography Central Switzerland was situated at the southern limit of the Germanic Basin and was separated from the Tethys realm by the Vindelician High (Ziegler 1990). In the studied area of the Central Alpine region three lithological units can be distinguished: the basal, terrestrial and clastic shallow-marine Mels-Formation, followed by the dolomitic Röti-Dolomit, and overlain by erosional relicts of red continental silty sandstones and dolomitic breccias of the Quarten-Formation.

Age indications have been sparse, and only a few bivalve species indicating lower Muschelkalk have been found in the Röti-Dolomit (for a summary see Ricour 1952 a,b; Trümpy 1959; Ricour 1963). However, the new palynological data presented in this paper indicate that the basal Triassic sediments are as old as Aegean, i.e., early Anisian. They also suggest that the transgression is heterochronous over a lateral distance of $10 \mathrm{~km}$, starting during the Aegean and continuing into the Bithynian and Pelsonian.

Recent biostratigraphic data from the Germanic Basin (Götz 1996) as well as palynofacies, conodont assemblages and sequence stratigraphic interpretations from three wells in Northern Switzerland (Fig. 5; Götz \& Gast 2007; Feist-Burkhardt et al. submitted) suggest a late early Anisian (Bithynian) and an early Anisian (Aegean) age, respectively, for the basin wide marine transgression at the base of the lower Muschelkalk. This transgression is recognized in the Wellenkalk1-Member of the Germanic Basin (Hagdorn et al. 1993; Götz 1994; Rameil et al. 2000) and in the Wellendolomit of Northern Switzerland (Götz \& Gast 2007; Feist-Burkhardt et al. submitted). Thus, the biostratigraphically dated marine transgres- sion in Central Switzerland occurred during the same substage as in Northern Switzerland but slightly earlier than in the Germanic Basin. These age assignments of the marine transgression, i.e., older in the south than in the north, is identical to those observed in the East Carpatian- and the Silesian Gate (Szulc 2000).

\section{Palaeogeographic implications}

The new biostratigraphic constraints for the region of Centraland Northern Switzerland (c.f. Götz \& Gast 2007; FeistBurkhardt et al. submitted) together with the palynologically dated Aegean, i.e., earliest Anisian, in the Scheidnössli section, the French Jura (Hochuli pers. information) and the wells in Northern Switzerland (Benken, Leuggern and Weiach) imply a southeast-northwest transgression onto the southern Tethyan border of the Vindelician High. This contradicts the previously dominating concept from the north, e.g., from the Germanic Basin. Our data together with those of Götz \& Gast (2007) suggest that during Early Triassic times Central Switzerland was located at the northern coast of the Tethys and not at the southern limit of the Germanic Basin. Furthermore, these findings support the idea of Einsele \& Schönenberg (1964), Szulc (2000) and Götz \& Gast (2007) of a marine passway, the Western Gate located in Switzerland, further to the east of the well known Burgundy gate.

Hence, marine environments established in Central- and Northern Switzerland at a time when terrestrial conditions prevailed farther north in the Germanic Basin. This implies a northward transgression in the region surrounding the Aar Massif. Thus, during Middle Triassic times the area surrounding the Aar Massif was situated at the northern shoreline of the Tethys, from where a marine passway/embayment reached northwards into the region of Northern Switzerland. However, it is still unclear on how far north this marine ingression reached, i.e., if it represented a marine embayment of the Tethys ocean or formed a real passage into the Germanic Basin.

\section{Acknowledgements}

The authors are thankful for the constructive reviews of Annette Götz and Joachim Szulc. The manuscript benefited greatly from comments of Peter Brack and Helmut Weissert.

\section{REFERENCES}

Aigner, T. \& Bachmann, G.H. 1992: Sequence-stratigraphic framework of the German Triassic. Sedimentary Geology 80, 115-135.

Alsharhan, A.S. \& Kendall, C.G.St.C. 2003: Holocene coastal carbonates and evaporites of the southern Arabian Gulf and their ancient analogues. Earth-Science Reviews 61, 191-243.

Arbenz, P. 1913: Bericht über die Exkursion der Schweizerischen Geologischen Gesellschaft in die Obwaldner Alpen vom 10. bis 13. September 1913. Eclogae Geologicae Helvetiae 12, 689-712. 
Bachmann, G.H. \& Lerche, I. 1999: Epicontinental Triassic. International Symposium, Halle/Saale, September 21-23, 1998. Schweizerbart'sche Verlagsbuchhandlung, Stuttgart, 1, 402 pp.

Baltzer, A. 1880: Der Mechanische Kontakt von Gneis und Kalk im Berner Oberland. Beiträge zur geologischen Karte der Schweiz 20, 25 pp.

Batten, D.J. 1996: Palynofacies and palaeoenvironmental interpretation. In: Jansonius, J. \& McGregor, D.C. (Eds.): Palynology: Principles and applications. American Association of stratigratigraphic Palynologists Foundation, Publisher Press, Salt Lake City, 3, 1011-1064.

De Saussure, H.-B. 1796: Voyages des Alpes III, 454 pp.

Einsele, G. \& Schönenberg, R. 1964: Epirogen-tektonische Grundzüge des süddeutschen Beckens und seiner südöstlichen Randgebiete im Mesozoikum. Publication Service géologique du Luxembourg 14, 139-164.

Escher von der Linth, H.-C. 1797: Geognostische Nachrichten über die Alpen. In Briefen aus Helvetien, 1. Brief Profil Gotthard-Zürichsee.

Feist-Burkhardt, S., Götz, A.E., Ruckwied, K. \& Russell, J.W. submitted: Palynofacies patterns, acritarch diversity and stable isotope signatures in the Lower Muschelkalk (Middle Triassic) of N Switzerland: evidence of thirdorder cyclicity. Swiss Journal of Geosciences, DOI 10.1007/s00015-0071235-z.

Flemming, B.W. 2004: Tidal Environments. In: Schwartz, M. (Ed.): Encyclopedia of Coastal Sciences, Kluwer, Dordrecht, 1180-1185.

Gianolla, P. \& Thierry, J. 1998: Triassic sequence stratigraphic framework of western European basins. In: De Graciansky, P.-C., Hardenbol, J., Jacquin, T. \& Vail, P.R (Eds.): Mesozoic and Cenozoic sequence stratigraphy of European basins. SEPM Special Publication 60, 643-650.

Götz, A.E. 1994: Feinstratigraphie und Zyklengliederung im Unteren Muschelkalk (Raum Creuzburg - Westthüringen). Beiträge zur Geologie von Thüringen Neue Folge 1, 3-12.

Götz, A.E. 1996: Palynofazielle Untersuchungen zweier Geländeprofile im Unteren Muschelkalk Osthessens und Westthüringens. Geologisches Jahrbuch von Hessen 124, 87-96.

Götz, A.E. \& Gast, S. 2007: The Anisian conodont fauna of Northern Switzerland: Evidence of a western Peri-Tethyal migration. Abstract, $15^{\text {th }}$ SwissSed Meeting of Sedimentology, Fribourg, 19.

Hagdorn, H., Horn, M. \& Simon, T. 1993: Vorschläge für eine lithostratigraphische Gliederung und Nomenklatur des Muschelkalks in Deutschland. In: Hagdorn, H. \& Seilacher, A. (Eds.): Muschelkalk. Schönthaler Symposium 1991, Goldschnek-Verlag Werner K. Weidert, Stuttgart, 39-46.

Hardenbol, J., Thierry, J., Farley, M.B., Jacquin, T., de Graciansky, P.-C. \& Vail, P.R. 1998: Triassic sequence chronostratigraphy/biochronostratigraphy. In: De Graciansky, P.-C., Hardenbol, J., Jacquin, T. \& Vail, P.R. (Eds.): Mesozoic and Cenozoic sequence stratigraphy of European basins. SEPM Special Publication 60, chart 8.

Heim, A. \& Heim, A. 1917: Der Kontakt von Gneiss und Mesozoikum am Nordrand des Aarmassivs bei Erstfeld. Vierteljahrsschrift der Naturforschenden Gesellschaft Zürich 62, 423-451.

Hochuli, P.A. 1998: Spore-Pollen. In: Hardenbol, J., Thierry, J., Farley, M.B., Jacquin, T., de Graciansky, P.-C. \& Vail, P.R. (Eds.): Mesozoic and Cenozoic sequence stratigraphy of European basins. SEPM Special Publication 60,781 .

Hurni, L., Malaguerra, C., Gubler, E., Spiess, E., Elsasser, H., Hussy, C., Feldmann, H.-U. \& Sieber, R. 2000: Digital Atlas of Switzerland. Swiss Federal Office of Topography, Bern.

Jordan, T.E., Schlunegger, F. \& Cardozo, N. 2001: Unsteady and spatially variable evolution of the Neogene Andean Bermejo foreland basin, Argentina. Journal South American Earth Sciences 14, 775-798.

Keller, B. 1989: Fazies und Stratigraphie der Oberen Meeresmolasse (Unteres Miozän) zwischen Napf und Bodensee. Dissertation, Universität Bern, Bern, 402 pp.

Kenig, F., Boichard, R. \& Purser, B.H. 1991: Holocene organo-sedimentary sequence of the Abu Dhabi coastal carbonate environment, United Arab Emirates. In: Bosellini, A., Brander, R., Flügel, E., Purser, B.H., Schlager, W., Tucker, M. \& Zenger, D. (Eds.): Dolomieu Conference on Carbonate Platforms and Dolomitization. International Association of Sedimentology, Oxford, 134-140.
Königsberger, J. 1909: Einige Folgerungen aus geologischen Beobachtungen im Aare-, Gotthard- und Tessinermassiv. Eclogae Geologicae Helvetiae $10,852-896$

Lusser, F. 1829: Geognostische Forschung und Darstellung des Alpenquerschnitts vom St. Gotthard bis Arth am Zugersee. Denkschrift der allgemeinen schweizerischen Gesellschaft für die gesamten Naturwissenschaften I, 144-172.

Lusser, F. 1842: Nachträgliche Bemerkungen zu den geognostischen Forschungen und Darstellungen des Alpenquerschnitts vom St. Gotthard bis Arth am Zugersee. Neue Denkschriften der Schweizerischen Naturforschenden Gesellschaft 6,14 pp.

Matter, A., Peters, Tj., Bläsi, H.R., Meyer, J., Ischi, H. \& Meyer, Ch. 1988: Sondierbohrung Weiach, Geologie (Text- und Beilagenband). Geologischer Bericht, Landeshydrologie und -geologie 6, $438 \mathrm{pp}$.

Mullis, J., Dubessy, J., Poty, B. \& O'Neil, J. 1994: Fluid regimes during late stages of a continental collision: Physical, chemical, and stable isotope measurements of fluid inclusions in fissure quartz from a geotraverse through the Central Alps, Switzerland. Geochimica et Cosmochimica Acta 58, 2239-2267.

Platt, N.H. \& Keller, B. 1992: Distal alluvial deposits in a foreland basin setting - the Lower Freshwater Molasse (Lower Miocene), Switzerland: sedimentology, architecture and paleosols. Sedimentology 39, 545-565.

Rameil, N., Götz, A.E. \& Feist-Burkhardt, S. 2000: High-resolution sequence interpretation of epeiric shelf carbonates by means of palynofacies analysis: an example from the Germanic Triassic (Lower Muschelkalk, Anisian) of east Thuringia, Germany. Facies 43, 123-144.

Ricour, J. 1952a: A propos de la «chaîne vindélicienne». Extrait du Compterendu sommaire des séances de la Société géologique de France, séance du 23. juin 11, 242-244.

Ricour, J. 1952b: Faune du Trias de la couverture des massifs cristallins externes des Alpes (Suisse et France). Extrait du Compte-rendu sommaire des séances de la Société géologique de France, séance du 17. novembre, 1, 301-304.

Ricour, J. 1963: Particularités paléogéographiques des Alpes occidentals françaises aux temps triasiques. Memoires hors-série de la Société géologique de France 1, 395-405.

Rohr, K. 1926: Stratigraphische und tektonische Untersuchung der Zwischenbildungen am Nordrand des Aarmassivs (Zwischen Wendenjoch und Wetterhorn). Beiträge zur Geologischen Karte der Schweiz, Neue Folge 57/1, $62 \mathrm{pp}$.

Southhard, J.B. 1991: Experimental determination of bedform stability. Annual Review of Earth and Planetary Sciences 19, 423-55.

Studer, B. 1853: Geologie der Schweiz. Stämpfli, Bern, 2, 497 pp.

Szulc, J. 2000: Middle Triassic evolution of the northern Peri-Tethys area as influenced by early opening of the Tethys ocean. Annales Societatis Geologorum Poloniae 70, 1-48.

Trümpy, R. 1959: Hypothesen über die Ausbildung von Trias, Lias und Dogger im Untergrund des schweizerischen Molassebeckens. Eclogae Geologicae Helvetiae 52, 435-448.

Vollmayr, T. \& Wendt, A. 1987: Die Erdgasbohrung Entlebuch 1, ein Tiefenaufschluss am Alpennordrand. Bulletin Schweizerische Vereinigung von Petroleum-Geologen und -Ingenieuren 125, 67-79.

Wright, V.P. \& Tucker, M. 1991: Calcretes. Blackwell Science Publications, Oxford, London, $360 \mathrm{pp}$.

Ziegler, P.A. 1990: Geological Atlas of Western and Central Europe. $2^{\text {nd }}$ Edition, Shell Internationale Petroleum Maatschappij B.V., The Hague, 239pp.

Manuscript received March 14, 2006

Manuscript accepted May 25, 2007

Published Online First August 31, 2007 